\title{
Implications of the Observed Seismic Performance of a Pile Supported Wharf for Numerical Modeling
}

Matthew J. Donahue, ${ }^{\text {a) }}$ M. EERI, Stephen E. Dickenson, ${ }^{\text {b) }}$ M. EERI, Thomas H. Miller, ${ }^{\text {b) }}$ M.EERI, Solomon C. Yim, ${ }^{\mathrm{c})}$ M.EERI

The seismic response and performance of pile supported wharves on sloping ground is not well documented due to a historical lack of instrumentation on port structures. Although general surface observations have been made at numerous ports following recent earthquakes, much more specific soil-foundation-structure-interaction data could have been obtained with the more wide spread employment of instrumentation. This paper presents the results of an empirical analysis of recorded strong motion data (SMD) from an array of instruments located on a pile supported wharf and in the adjacent free field. The recorded SMD have provided insight into the behavior of wharf backland soils as well as structural response due to seismic wave passage and potential torsional behavior due to the configuration of structural and foundation elements. Presented herein are the results of an investigation of the seismic response of Berth 24/25 at the Port of Oakland, California during the M7.0 Loma Prieta earthquake. The primary objectives of this project were to evaluate SMD from an instrumentation array at Berth $24 / 25$ and to identify the limitations inherent in capturing the complete dynamic character, including soil structure interaction, of a pier or wharf with a structural model.

In engineering practice there is ongoing debate concerning the limitations of $3 \mathrm{D}$ structural modeling of wharves and piers for seismic analysis. A numerical model of Berth 24/25 was validated using ground motions recorded during the 1989 Loma Prieta earthquake with a twelve channel array placed on and adjacent to the structure. Through a series of simulations, the effect of variation of selected model parameters has been evaluated by comparison to recorded wharf motions. Analyses using design level input motions were performed to evaluate applicability of the full 3D model. The project is expected to serve the professional engineering community by providing guidance in selecting appropriate techniques for seismic analysis and subsequent upgrade of existing port facilities.

\section{INTRODUCTION}

Construction of Berth 24/25 at the Port of Oakland (Port) was completed in 1977. The facility has overall dimensions of $493 \mathrm{~m}$ length by $20 \mathrm{~m}$ width. Wharf support is provided by $46 \mathrm{~cm}$ square prestressed vertical and batter piles arranged in a pattern that repeats itself every fifteen meters, and a steel sheet pile cut-off wall running the length of the in-shore side

\footnotetext{
a) Graduate Student

b) Associate Professor

c) Professor

a-c) Department of Civil, Construction and Environmental Engineering, Oregon State University, 202

Apperson Hall, Corvallis, OR, 97331
}

Donahue - 2 
of the facility. A schematic and photo of current Port facilities are provided in Figures 1a and $1 b$, respectively. A cross section of the wharf as it existed at the time of the Loma Prieta earthquake and typical section of the 3D structural model are provided in Figures 1c and 1d, respectively.

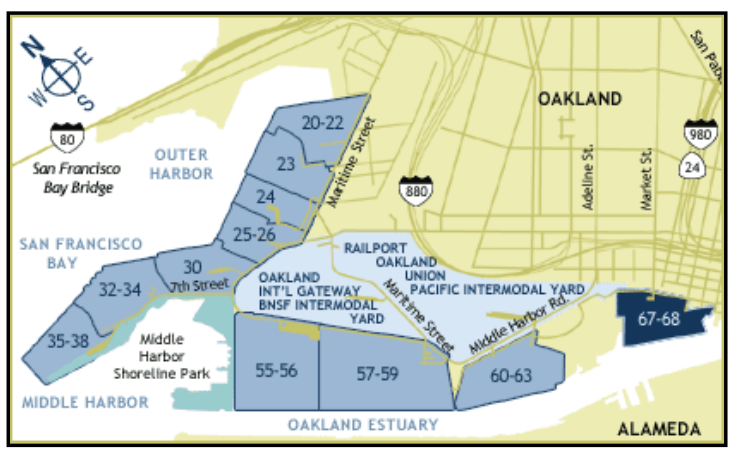

a) Present-day Port facilities

(Port of Oakland, 2003)

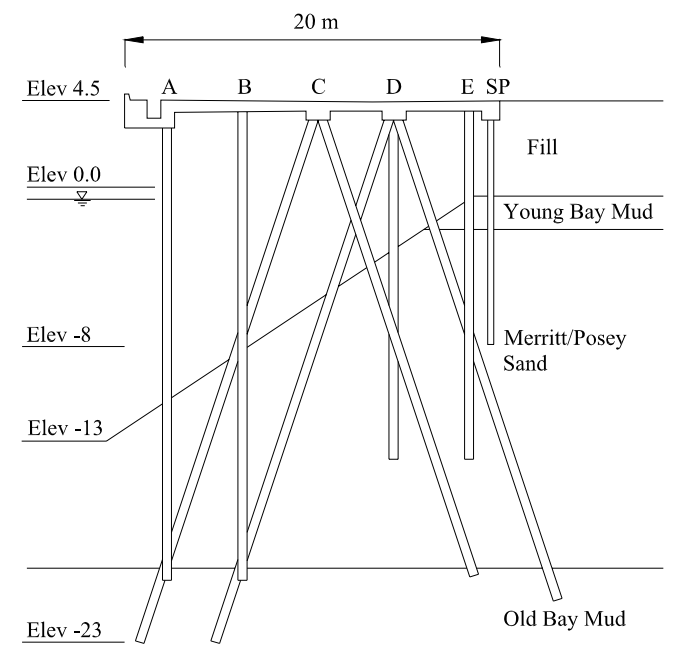

c) Berth 24/25 cross section

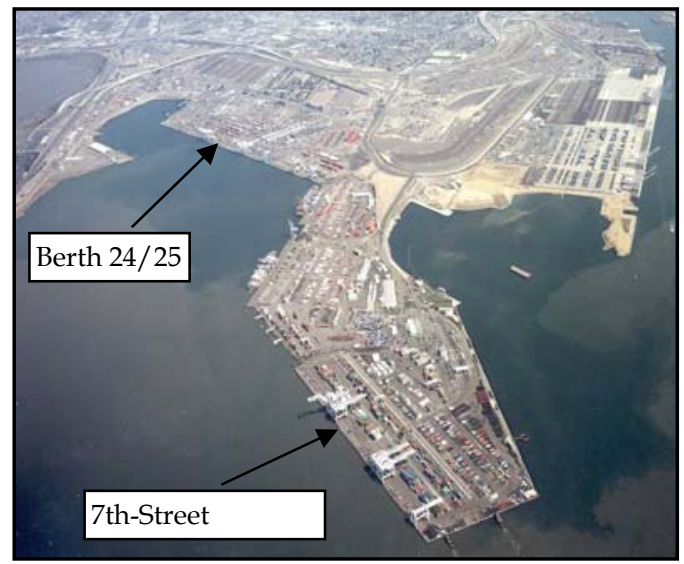

b) Overview of Port facilities

(Labasco, 2003)

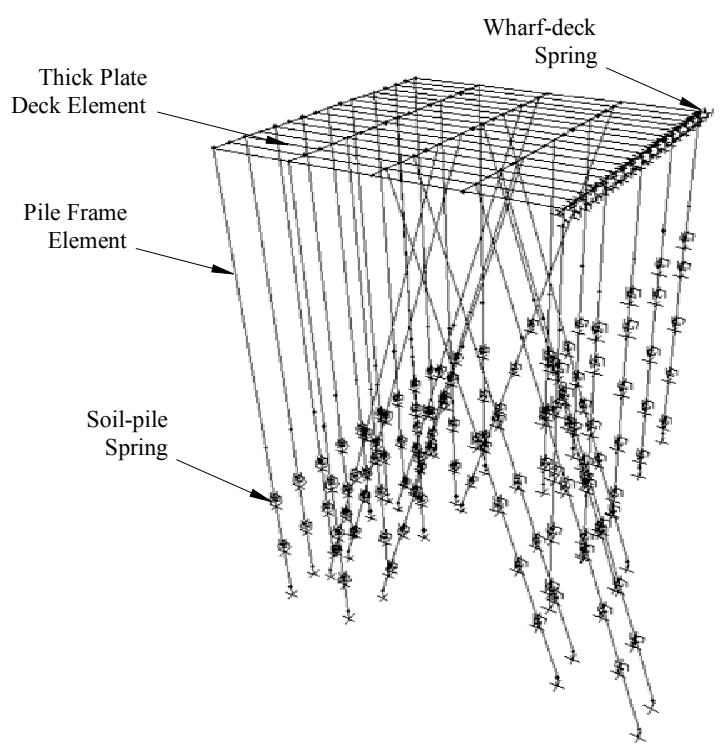

d) Model Repeatable Section

Figure 1 - General Port and wharf schematics

On October 17, 1989, the Port of Oakland was subjected to strong ground motions (ground surface peak acceleration approximately $0.30 \mathrm{~g}$ ) generated by the Loma Prieta earthquake. Prior to this event the California Seismic Monitoring and Instrumentation Program (CSMIP) had installed a twelve-channel array of accelerometers on and adjacent to Berth 24/25. Although Berth 24/25 was not substantially affected during this event, other Port facilities, such as the $7^{\text {th }}$-Street Terminal, suffered significant levels of damage. Spreading and settlement caused by liquefaction at the $7^{\text {th }}$-Street Terminal resulted in permanent rock dike deformation, settlement of the backland crane rail, broken or damaged 
batter piles, and settlement of an adjacent building triggering utility damage (Egan et al. 1992 and TCLEE, 1998).

As a result of exposure to strong shaking and the observed damage at the $7^{\text {th }}$-Street Terminal, Berth 24/25, as well as many other Port facilities, was heavily scrutinized for susceptibility to damage under current design level ground motions. Previous investigations of the seismic response of Berth 24/25 using 2D non-linear pushover analyses (CH2M HILL and Ben C. Gerwick, 2000) and 3D non-linear modeling techniques (Norris et al., 1991) have been performed. The work in this project enhances these previous analyses by assessment of model input parameters through comparison of numerical modeling output to SMD available for Berth 24/25. Previous analyses have been further expanded upon by employment of software widely used by the port structural engineering community at large, and by reporting specific soil spring stiffness values developed to characterize pile-soil interaction.

The numerical analysis described in this paper was performed with widely used structural modeling software (Computers and Structures, Inc., 2000). Wharf model behavior was primarily governed by springs used to characterize pile-soil and wharf to cut-off wall interaction. Different stiffnesses for these spring elements were used and the resulting output was compared to recorded SMD. The goal of this comparison is to determine appropriate modeling techniques and values for governing parameters to be used in further $2 \mathrm{D}$ and $3 \mathrm{D}$ analyses of facilities at the Port.

\section{EMPIRICAL EVALUATION OF STRONG MOTION DATA}

Figure 2 illustrates the layout of accelerometers installed on and adjacent to Berth 24/25 at the Port. Only the horizontal channels were used for analyses performed in this project. Empirical analysis of recorded SMD for port structures is a useful tool for elucidating structural response of port facilities and observation of phenomena including torsion and seismic wave passage. Torsion may be induced by incoherent motions between different sections of the wharf due to the "wave passage" effect of seismic energy as it moves past the long wharf structure. Analysis of SMD can also be used to demonstrate shifts in period between comparable backland and structure channels signifying non-linear soil response and soil-foundation-structure-interaction. For Berth 24/25, possible torsion was evaluated by calculating relative displacement-time histories between parallel channels along the wharf. Figure 3 shows the relative displacement in the in-shore/out-shore (i.e. transverse) direction between channels 6 and 9. Relative displacement was calculated as the difference between the absolute values for displacement at each increment of the time history. Given the total wharf length of $493 \mathrm{~m}$, the maximum relative displacement of $4.2 \mathrm{~cm}$ between channels 6 and 9 indicates negligible torsion and a low possibility of resulting damage along the wharf solely due to this response.

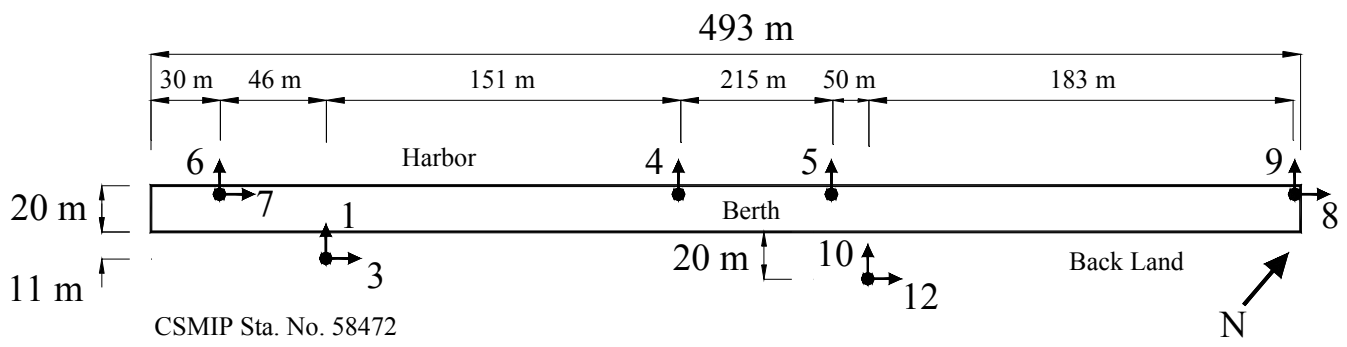

Figure 2 - Berth 24/25 accelerometer layout

Donahue - 4 


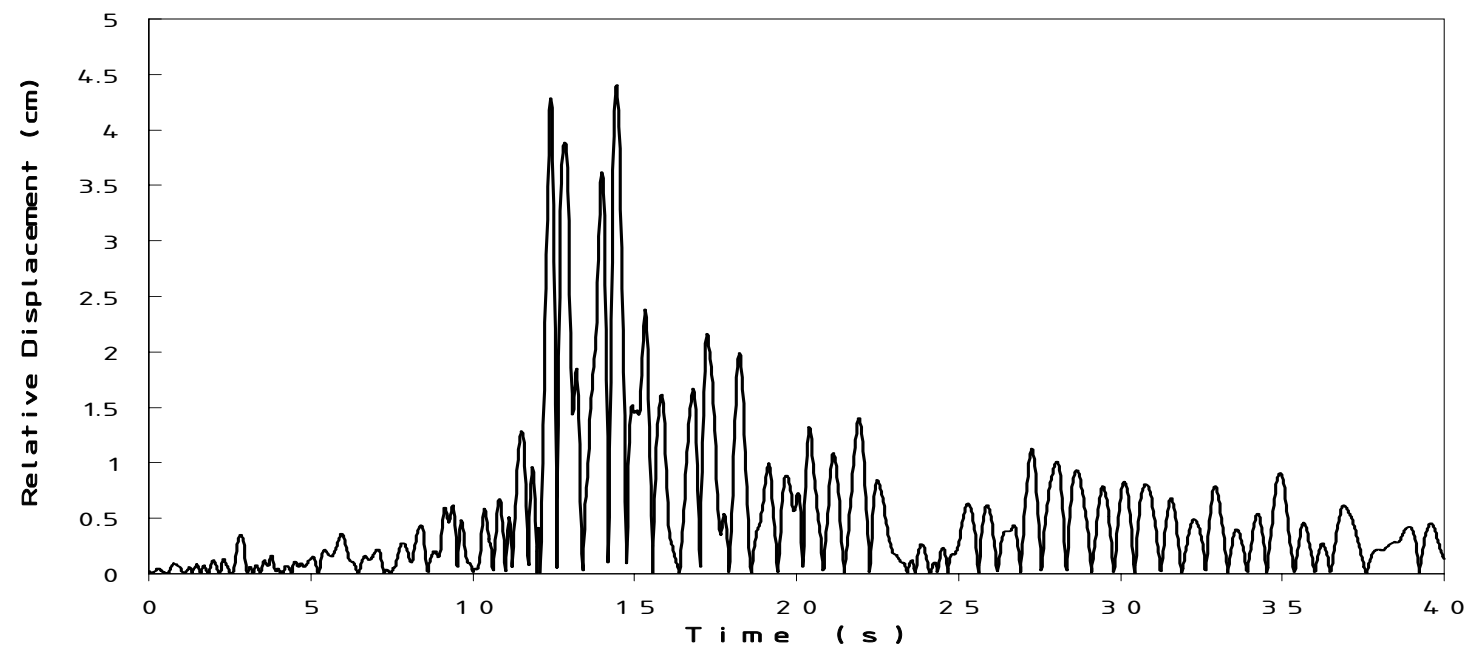

Figure 3 - Relative displacement between channels 6 and 9

The potential for liquefaction of shallow sandy fill below and adjacent to Berth 24/25 is evident from uncorrected standard penetration test (SPT) N-values ranging from 5 to 22 blows $/ 30 \mathrm{~cm}$ as reported during subsurface explorations performed for design of the wharf (Port of Oakland, 1977) and from previous investigation of earthquake-induced embankment deformations performed as part of the Wharf Embankment and Strengthening Program (WESP) at the Port of Oakland (URS Greiner Woodward Clyde, 2000). This geotechnical data applies to the landward side of the wharf from the central area to the Northeastern end. Field observations after the Loma Prieta earthquake indicate the occurrence of elevated excess pore pressures and possibly full liquefaction at disparate locations along Berth 24/25 (Serventi, 2003). This is supported by SMD in which absolute displacement-time histories are compared for parallel backland accelerometer channels (Figure 4). At approximately fourteen seconds in the time history, the channel 10 ground motions exhibit a slight shift (i.e. lengthening) of period as compared to that of channel 1. This change in frequency content for the channel 10 time history is considered to be an indicator of loss of soil stiffness under significant shaking. A similar occurrence is observable for comparison of channels 3 and 12 . Given the relatively small separation distance between channels 1 and $10(278 \mathrm{~m})$, it is likely that liquefaction and/or stiffness loss of Northeast backland soils occurred as a result of significant shaking.

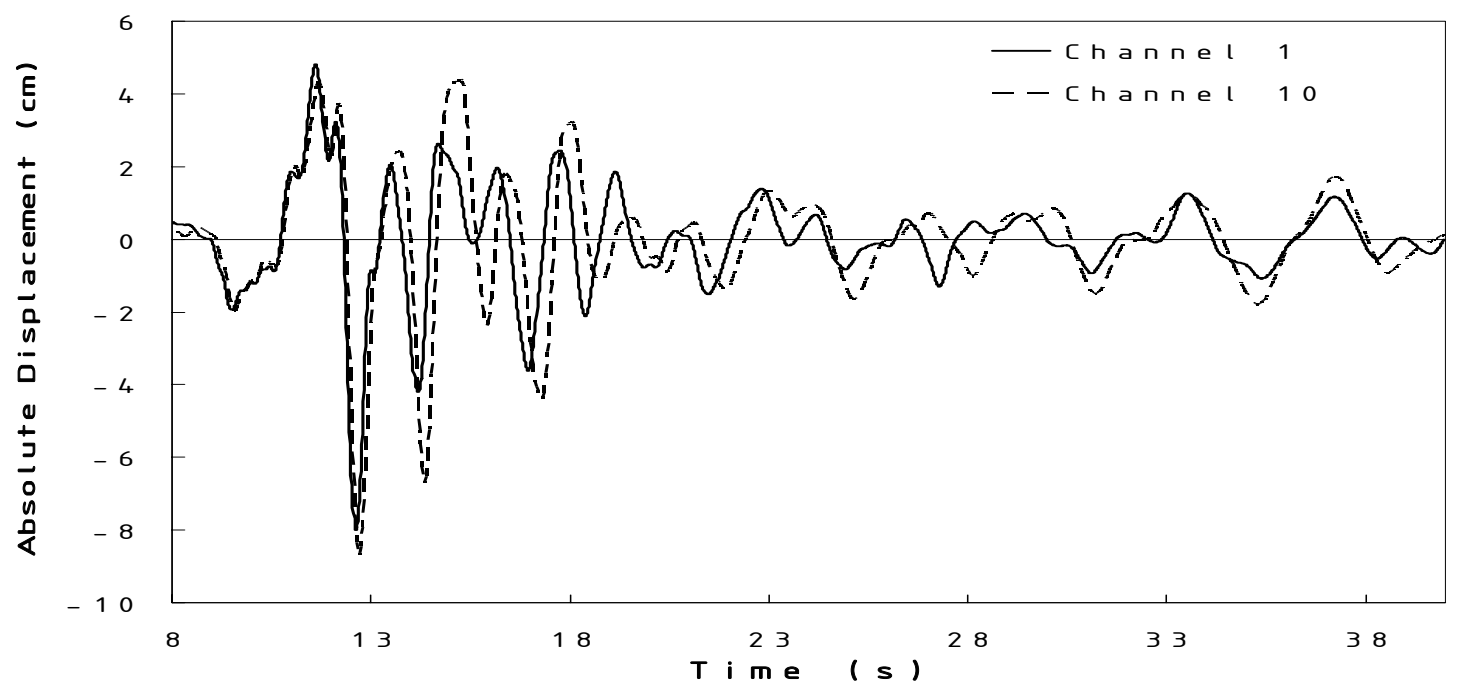

4a) Displacement-time histories for Channels 1 and 10

Donahue - 5 


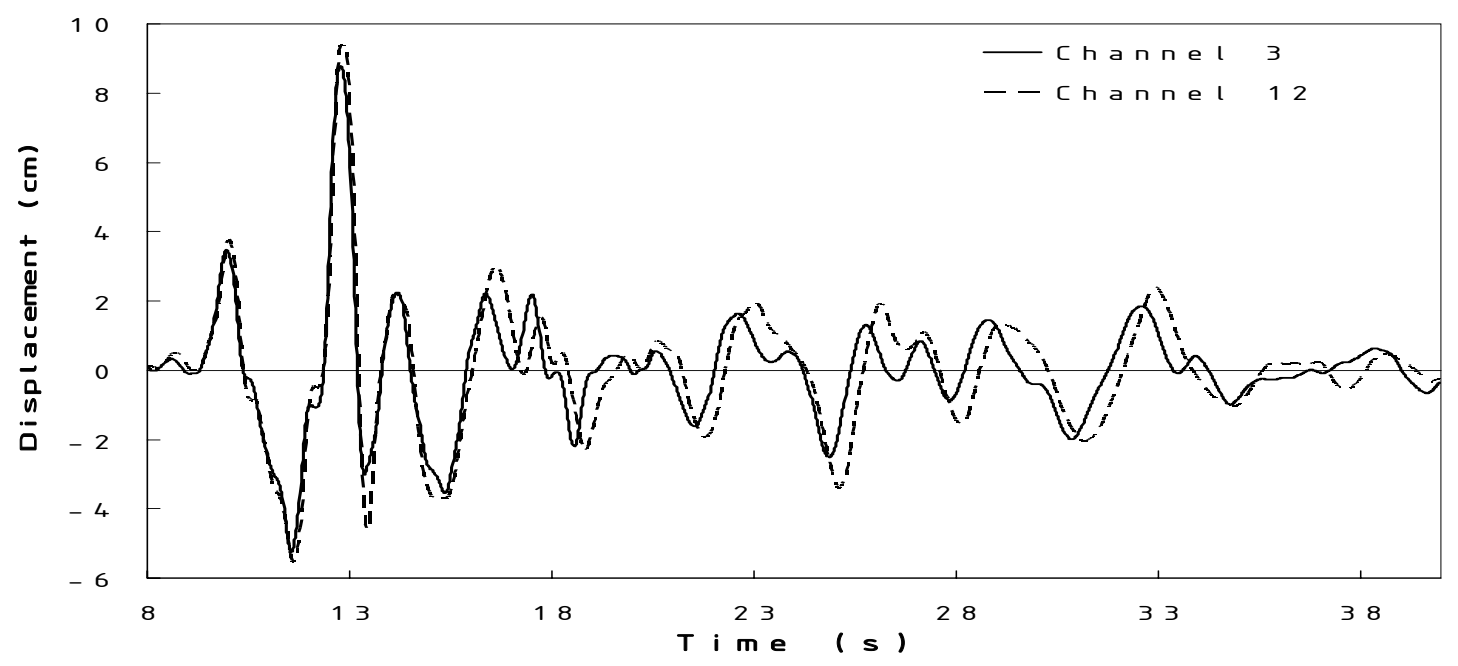

4b) Displacement-time histories for Channels 3 and 12

Figure 4 - Comparison of displacement-time histories

This assessment of recorded SMD is supported by the pavement settlement and minor crane rail deformations observed by Port personnel after the Loma Prieta earthquake (Serventi, 2003).

\section{INPUT GROUND MOTIONS FOR THE DYNAMIC STRUCTURAL MODEL}

Recorded acceleration-time histories for channels 1 and 3 were deconvoluted to the depth of the lowest pile tip elevation with a $1 \mathrm{D}$ equivalent linear dynamic soil response model (EduPro Civil Systems, Inc. 1999) to generate the input acceleration-time histories for use in the structural analysis. Channels 1 and 3 were selected as there was no evidence of liquefaction in the southeast wharf backland area, as compared to that discussed in the previous section for the area surrounding channels 10 and 11 . Given the $11 \mathrm{~m}$ distance of the channel 1 and 3 accelerometer behind the inboard edge of the wharf, influence of the dynamic wharf response on the recorded ground motions is thought to be minimal. Table 1 delineates the soil profile used for geotechnical analyses including values for plasticity index (PI), average shear wave velocity $\left(\left(\mathrm{V}_{\mathrm{S}}\right)_{\text {avg }}\right)$, damping ratio $(\xi)$ and unit weight $\left(\gamma_{\mathrm{T}}\right)$. Data were obtained from several

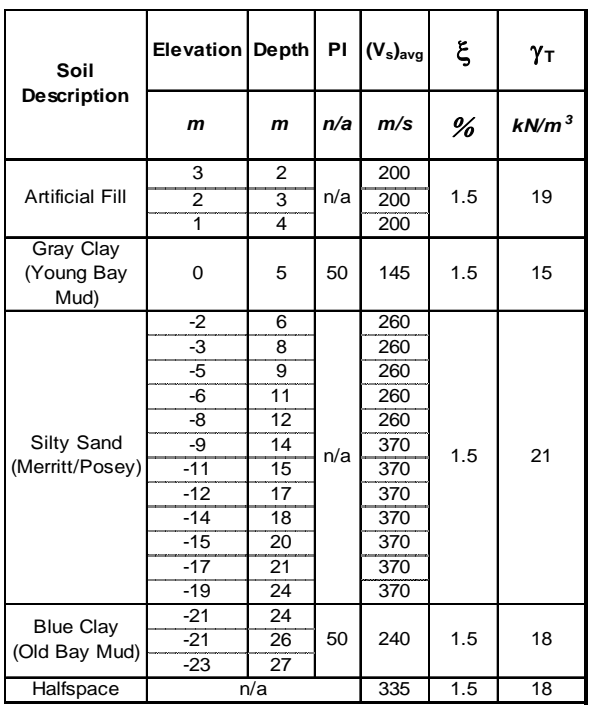

Table 1 - Profile for Dynamic Soil Response Analysis sources (USGS, 1992; URS, 2000). Non-linear soil stiffness and damping properties were modeled using the well known relationships for sand (Seed and Idriss, 1970 and Seed, et al., 1986) and clay (Vucetic and Dobry, 1991). Given the soft Bay Mud beneath Berth 24/25, ground surface motions were reduced when deconvoluted to a depth consistent with the lowest pile tip elevation of $-23 \mathrm{~m}$ from mean low water. The peak ground accelerations (PGAs) for channels 1 and 3 are $0.28 \mathrm{~g}$ and $0.22 \mathrm{~g}$, respectively. The acceleration-time histories for these records are given in Figure 5a and 5b (California 
Department of Conservation, 1989). The resulting computed soil response at depth (i.e. structural model input) yielded PGAs of $0.17 \mathrm{~g}$ and $0.12 \mathrm{~g}$ for channels 1 and 3 , respectively.

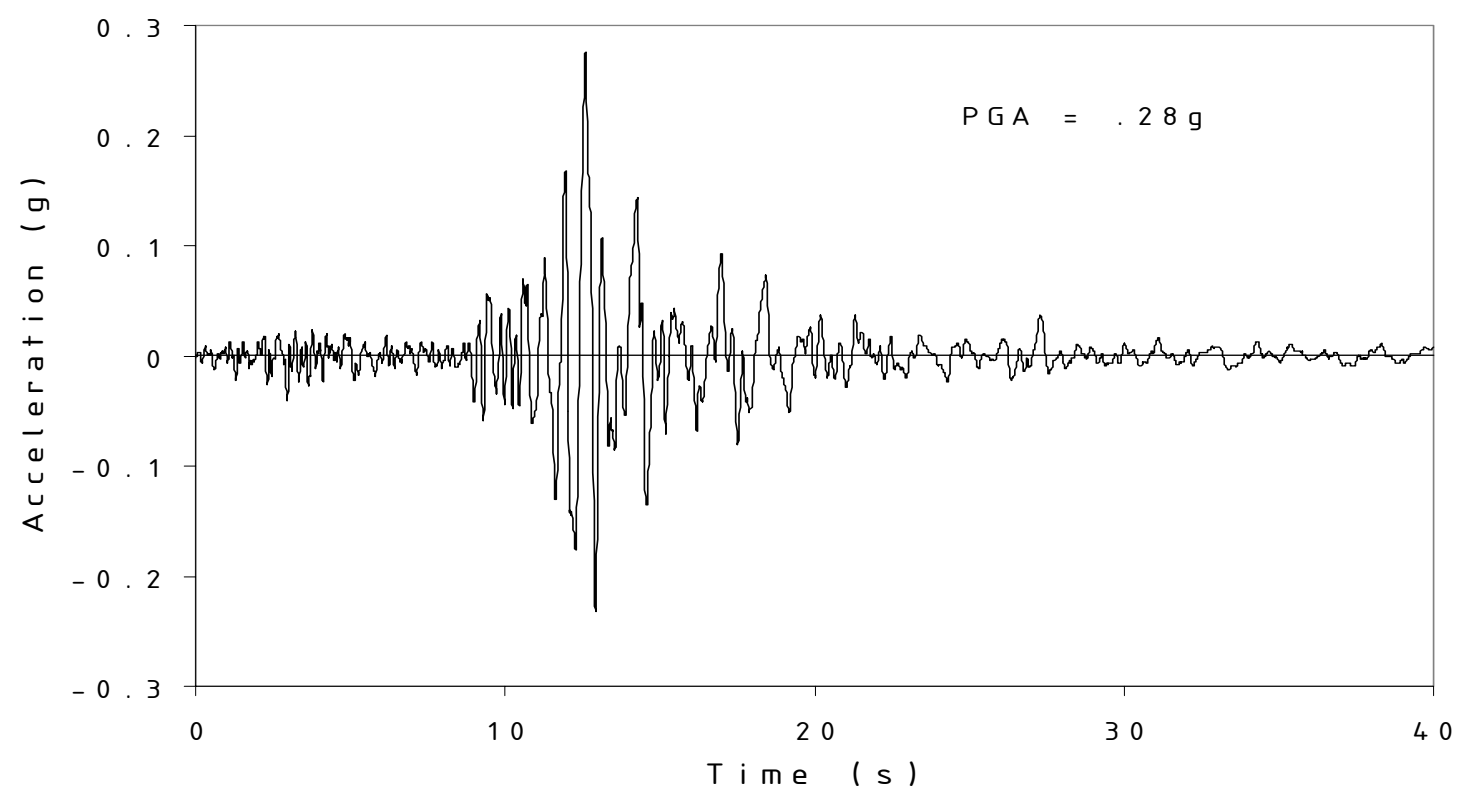

5a) Channel 1 acceleration-time history at ground surface

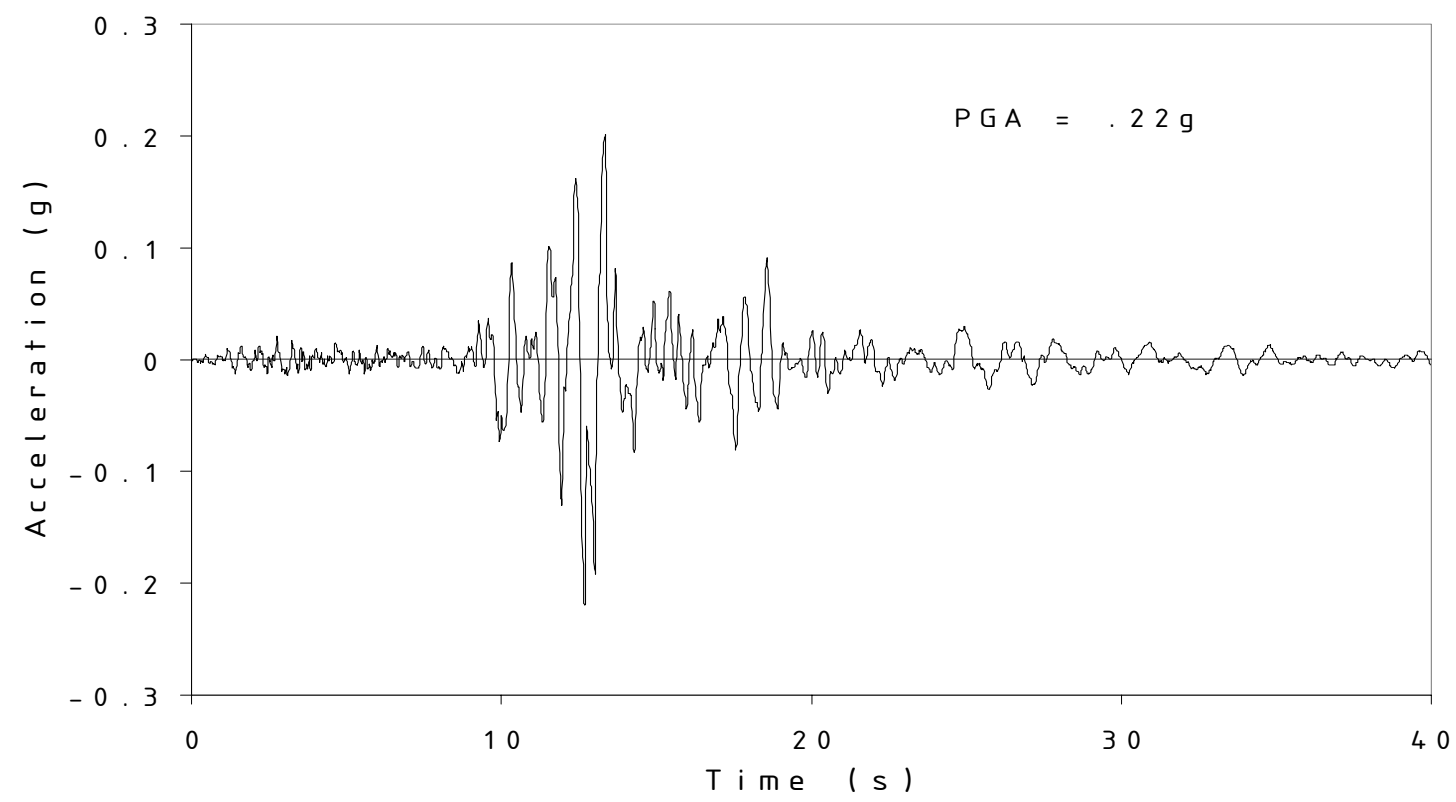

5b) Channel 3 acceleration-time history at ground surface

Figure 5 - Berth 24/25 acceleration-time histories

\section{SEISMIC MODELING TECHNIQUES}

Uncertainties concerning seismic analysis and design of port facilities often revolve around the difference between the linear-elastic-lumped-mass method used in structural analyses and the non-linear-continuum method used in geotechnical analyses. Both of these techniques are typically applied in a manner consistent with a performance-based design approach allowing for analysis and consideration of response either up to or beyond the limit

Donahue - 7 
of elastic behavior (TCLEE, 1998; International Navigation Association, 2001). An explanation of each method is given below.

Linear-elastic-lumped-mass method: This approach can involve development of a 2D or 3D structural model. For port facilities this method typically entails a 2D push-over analysis of a model consisting of elastic beam elements configured to describe the wharf deck and support piles. Soil-structure interaction is captured by use of elastic-plastic springs attached at intervals along the beam elements and representing wharf support piles. The model is loaded until a failure mechanism forms when a predetermined element capacity is reached. The deformation at the point of initial yield caused in the model by the induced load is considered to be the displacement capacity. The displacement demand is then determined by seismic response spectra or time history analyses. If the demand does not exceed the capacity then the subject structure is considered to be acceptably designed. This procedure has been discussed by numerous investigators (Weismair et al., 1998; Weismair et al., 2001; Roth and Dawson, 2003). This method has the advantage of simplicity, but the distinct disadvantage of not incorporating subsurface loading of piles due to earthquake induced soil deformations.

Non-linear-continuum method: This geomechanical approach involves construction of a 2D model with a finite difference or finite element mesh to describe soil conditions adjacent to and below the structure of interest. Use of this method may include allowance for permanent deformation of modeled soils due to loss of strength caused by increased pore pressure and/or exceedance of shear capacity. Structural elements are also included in the model. These elements are allowed to behave inelastically and have nodes that are attached to nodes of the soil mesh. Soil-structure interaction is captured by use of elastic-plastic springs that incorporate degradation of yield strength due to significant shaking. Acceleration-time histories are then applied to the model. The resulting wharf and soil slope deformations from the model are then considered to be the displacement demand (Johnson et al., 2001; Roth et al. 2003). This method has the advantage of capturing the phenomena governing wharf seismic response described above that are not accounted for in the linearelastic-lumped-mass method. However, a disadvantage is the balance required between soil mesh grid size and model computation time. Grid size is typically chosen such that the resolution sufficiently captures soil behavior yet minimizes computational demand. As the nodes of structural elements embedded in the soil continuum are attached to soil mesh nodes this may result in a spacing for contiguous structural elements (i.e. support piles) that is too large to accurately describe their behavior.

Neither of the methods described incorporate the 3D effects of interaction between structural elements and soil-structure interaction. The intent of the modeling approach for this project was to incorporate some of the modeling techniques listed above, capture 3D effects, and to compare the results of using these techniques to actual recorded earthquake data.

\section{D STRUCTURAL MODEL}

Figure 1d gives a 3D view of a portion of the Berth 24/25 3D structural model. As-built plans (Port of Oakland, 1977) from the original construction of Berth 24/25 were used to gather information on pile and deck geometry and material properties. Concrete compressive strengths $\left(\mathrm{f}_{\mathrm{c}}^{\prime}\right)$ were assumed to be approximately $20 \%$ greater than the specified 28 day values, consistent with the 12 year age of the structure at the time of the Loma Prieta event. 
Masses were assigned to the pile nodes based on tributary pile lengths, assigned to deck nodes based on tributary deck area, and calculated with a concrete unit weight of $24 \mathrm{kN} / \mathrm{m}^{3}$. The same unit weight was used to define the material properties that determine the dead load of frame and thick plate elements. Energy dissipation was incorporated into the structural model as $10 \%$ modal damping. A description of significant parameters used to model structural elements follows.

Support piles. Each $46 \mathrm{~cm}$ square prestressed vertical and batter pile was modeled as a series of frame elements. The lengths of the frame elements for piles in each row were determined by unsupported pile length (i.e. region between pile deck and intersection of the design mud line) and selected depths for assignment of soil springs. Soil springs were assigned at depth intervals ranging from every 1.5 to $3 \mathrm{~m}$ below the design mud line to represent soil-pile interaction for each soil layer. Concrete material properties for support piles are $\mathrm{f}_{\mathrm{c}}^{\prime}=49,800 \mathrm{kPa}$ and modulus of elasticity $(\mathrm{E})=3.34 \times 10^{7} \mathrm{kPa}$.

Soil springs. Soil-pile interaction was modeled using a series of elastic-plastic, nonlinear spring elements. These elements allow for an elastic-spring stiffness and limiting failure load, beyond which the spring has very nearly zero stiffness, and act in all degrees of freedom. The elements were created with zero length and connected to fixed and free nodes sharing the same coordinates. Spring stiffnesses were calculated for each pile row at approximate depth intervals ranging from 1.5 to $3 \mathrm{~m}$ along the pile, resulting in fourteen different element types. The uppermost pile nodes, representing the pile mud-line interface, were not assigned non-linear spring elements, as soil in this region is not likely to provide much resistance. Secant stiffness $\left(\mathrm{K}_{\mathrm{sec}}\right)$ values were derived from P-y curves formulated using the American Petroleum Institute (API) method (API, 1987) by calculating the slope of a straight line drawn from the origin to intersect the upper bound of the curve. This upper bound represents the ultimate lateral soil load as calculated using the API method. $\mathrm{K}_{\mathrm{sec}}$ values ranged from 5.7 to $224 \mathrm{~N} / \mathrm{cm}^{2}$ for clay and 4.3 to $15.7 \mathrm{kN} / \mathrm{cm}^{2}$ for sand. These $\mathrm{K}_{\mathrm{sec}}$ values represent stiffness per unit length along the pile and were multiplied by tributary pile lengths to determine elastic spring stiffness values for each of the fourteen types of non-linear spring elements. The yield load assigned to these elements determines the point at which the spring behaves plastically and was taken as the ultimate lateral soil load. It should be noted that model results showed that deformations for non-linear spring elements never exceed the elastic range corresponding to the line defining $\mathrm{K}_{\mathrm{sec}}$. The soil stiffness in this range of deformation then is higher than the values used for structural modeling. Use of the API method for calculating $K_{\text {sec }}$ values was employed as it is a typical engineering procedure used in similar types of structural analyses. Group effects on lateral pile deformation and subsequently P-y curve values were considered negligible as center to center, horizontal spacing of vertical piles is $3.8 \mathrm{~m}$. In some cases horizontal spacing between batter and vertical piles in the longitudinal wharf direction is $1.8 \mathrm{~m}$ which could result in reduced lateral pile capacity due to group effects. A possible refinement to the soil spring approach used for the structural model would be modification of selected P-y curves using p-multipliers (US Department of Transportation, 1996).

Wharf deck. The wharf deck was modeled as an array of thick plate elements $46 \mathrm{~cm}$ in depth. Concrete material properties used to model the wharf deck are $\mathrm{f}^{\prime}{ }_{\mathrm{c}}=33,950 \mathrm{kPa}$ and $\mathrm{E}$ $=2.76 \times 10^{7} \mathrm{kPa}$. 
Pile caps. Piles caps in rows A, C and D were modeled using frame elements geometrically consistent with the cap portion below the wharf deck. Material properties were the same as those used for the wharf deck thick plate elements.

Steel sheet pile cut-off wall. The steel sheet pile cut-off wall was modeled as a series of linear springs attached to each deck node on the backland side of the wharf. Stiffness values for the in-shore/out-shore and vertical directions were calculated as the flexural and axial elastic stiffnesses per unit length of wall, respectively. Flexural and axial stiffnesses were determined to be 25 and $5800 \mathrm{kN} / \mathrm{cm}$, respectively. Given the comparatively rigid connection of the individual sheet piles, flexural stiffness in the longitudinal direction along the wharf was assumed to be infinite. These values do not account for the influence of backland soils on sheet pile wall stiffness.

The modeling techniques described in the previous section were used to create a base 3D wharf section that repeats itself every fifteen meters. This repeatable section was then replicated to create the entire model. Static dead load and acceleration-time history analyses were then performed and combined.

Ground Motions and Seismic Performance Criteria: Separate acceleration-time history analyses were conducted using records from the 1989 Loma Prieta and 1995 Kobe events, each of which was comprised of two horizontal and orthogonal components applied simultaneously. Vertical ground motions were not available for the Southeast region of Berth 24/25 for the Loma Prieta earthquake. Loma Prieta records for channels 1 and 3 were deconvolved to the bottom pile tip elevation and have PGAs of $0.17 \mathrm{~g}$ and $0.12 \mathrm{~g}$, respectively. This method is typically used in engineering practice as an estimation of the ground motions experienced by a pile supported wharf. The same input ground motions used in an acceleration-time history analysis are applied to all fixed nodes in the structural model including those attached to springs employed to capture pile-soil interaction. This practice was dictated by the lumped-mass structural model used for this project. Actual ground motions at Berth 24/25 would likely increase as they propagate up through the soil profile and along the support piles. The effect of this condition could be further explored via sensitivity studies not performed for this project.

Recorded and scaled ground motions from the 1995 Kobe earthquake, Amagasaki station, were used as they had been selected as representative of ground motions corresponding to the $10 \%$ probability of exceedance in 50 year design event in previous seismic analyses at the Port (URS Greiner Woodward Clyde, 2000). This selection is significant based on the pulse or near-fault effects that port facilities were subjected to during the Kobe event, and also a matter of interest at the Port of Oakland given the seismic character of the surrounding area. Of primary concern are the San Andreas and Hayward faults that are approximately 20 and $10 \mathrm{Km}$ away, respectively. Use of near-fault ground motions is further supported by recent investigations of the influence of ground motion characteristics on structural response and design (PEER, 2003). PGAs for both components of the Amagasaki records are $0.58 \mathrm{~g}$. The acceleration-time histories for the fault normal and parallel components of this event are given in Figures 6a and 6b. Despite the orientation and proximity of faults adjacent to the Port, the Kobe ground motions were applied to the structural model to provide the most significant shaking in the direction with lateral support provided by wharf batter piles. Therefore, the fault normal and parallel components of the Kobe event were applied in the transverse and longitudinal directions of the wharf, respectively. 


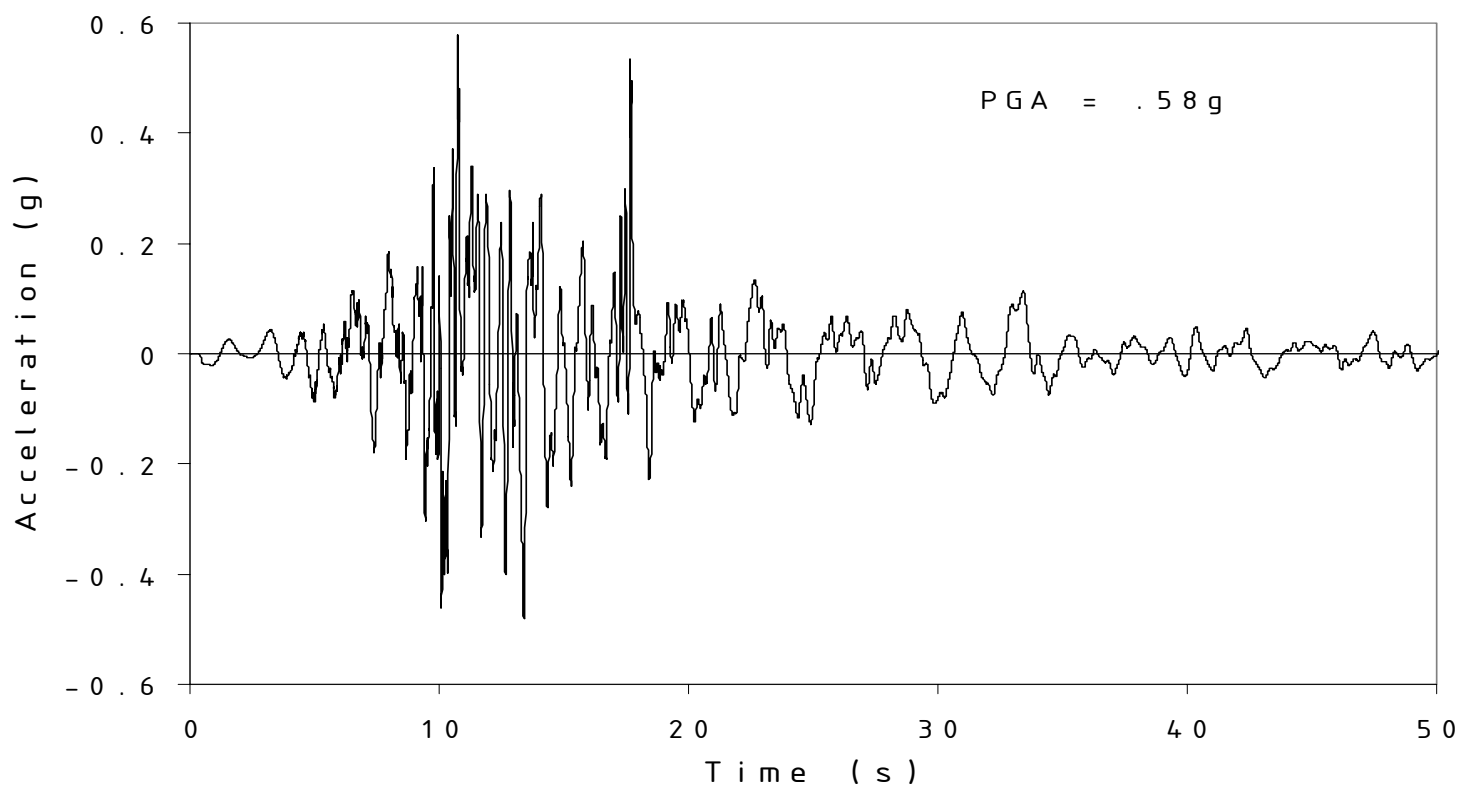

6a) Fault normal acceleration-time history

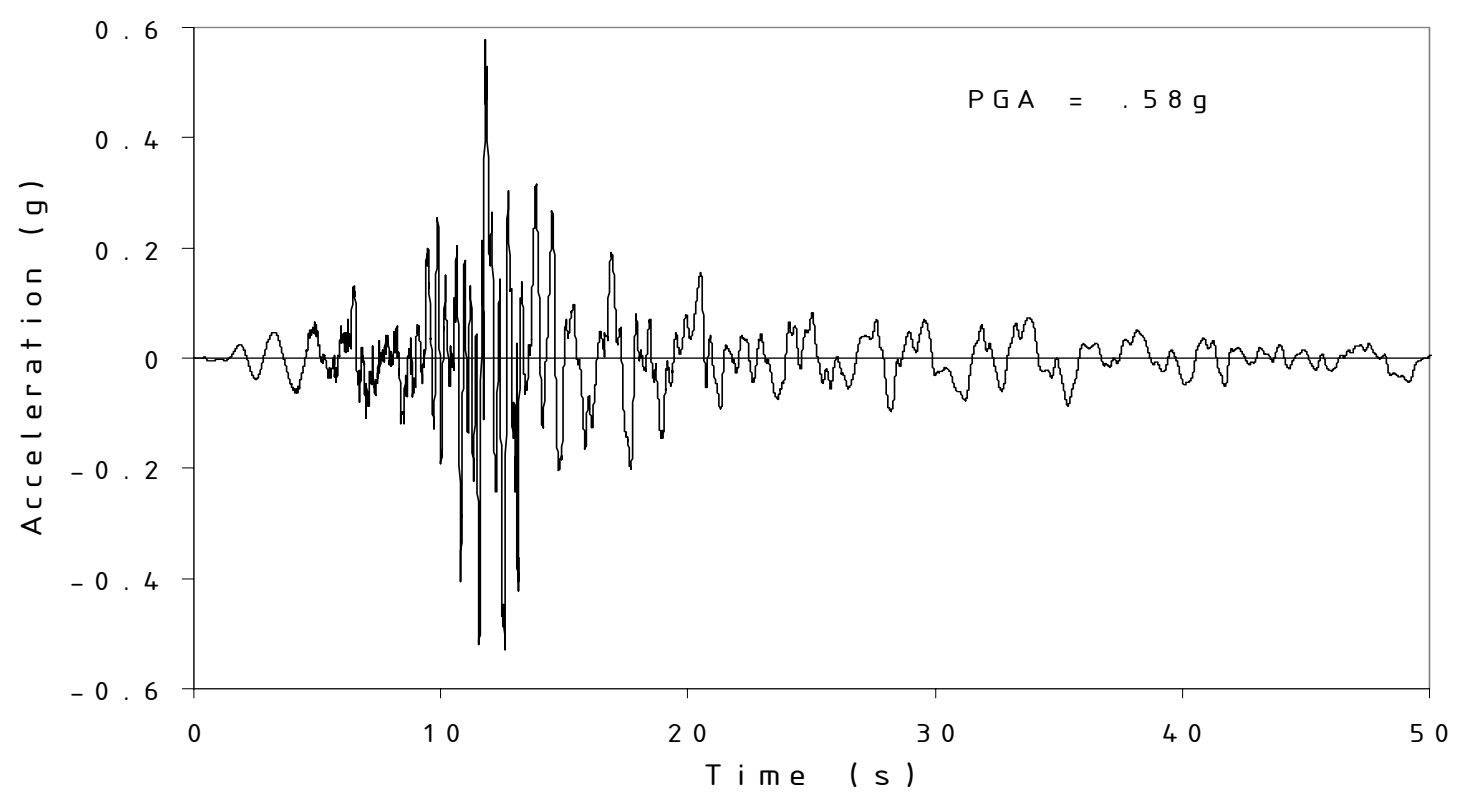

6b) Fault parallel acceleration-time history

Figure 6 - Acceleration-time histories used for numerical modeling (Amagasaki Station, 1995 Kobe earthquake, Scaled)

Three levels of seismic performance for wharf structures have been defined by the Port of Oakland. The Level I limit state allows for minor repairable damage under ground motions having a probability of exceedance of $50 \%$ in 50 years. The Level II limit state allows for controlled repairable damage without interruption of normal operations under ground motions having a probability of exceedance of $10 \%$ in 50 years. The third, or post Level II, limit state allows for unrepairable damage, but prohibits collapse under ground motions having a probability of exceedance greater than those defined for the Level II limit state 
(CH2M HILL and Ben C. Gerwick, 2000; Lobedan et al., 2001). Loma Prieta ground motions are those associated with the Level I event, while Kobe ground motions have been used to define Level II shaking in past analyses at the Port.

\section{DISCUSSION OF STRUCTURAL MODEL RESULTS}

Recorded and modeled displacement-time histories for the Loma Prieta earthquake were compared to evaluate model performance. Maximum pile forces from both the Loma Prieta and Kobe events were examined to estimate the number of piles damaged and/or failed for each level of shaking.

Loma Prieta Displacement-time histories. Figures 7 and 8 compare absolute displacement-time histories for channels 6 and 7 and their corresponding model node. All other wharf model nodes showed similarly well matched results to the corresponding recorded data. A number of simulations were run with variation up to $\pm 20 \%$ about the mean $\mathrm{K}_{\mathrm{sec}}$ values. Results of these analyses showed negligible difference for absolute displacement-time histories. The lack of effect from variation of soil spring stiffness is a result of very large $\mathrm{K}_{\mathrm{sec}}$ values attributable to Berth $24 / 25$ soil conditions. Analyses were also run by removing the non-linear and linear spring elements from the model to demonstrate their impact on model accuracy. As can be seen in Figure 9, relevant and accurate displacement time histories are not achieved in the longitudinal direction unless the soil and sheet pile wall spring elements are incorporated into the model. However, wharf behavior in the transverse direction is not as dependent on the use of spring elements. Wharf stiffness in the transverse direction is predominantly controlled by the batter piles. Therefore, displacement-time histories in this direction showed negligible difference compared to results from simulations with both spring types in place.

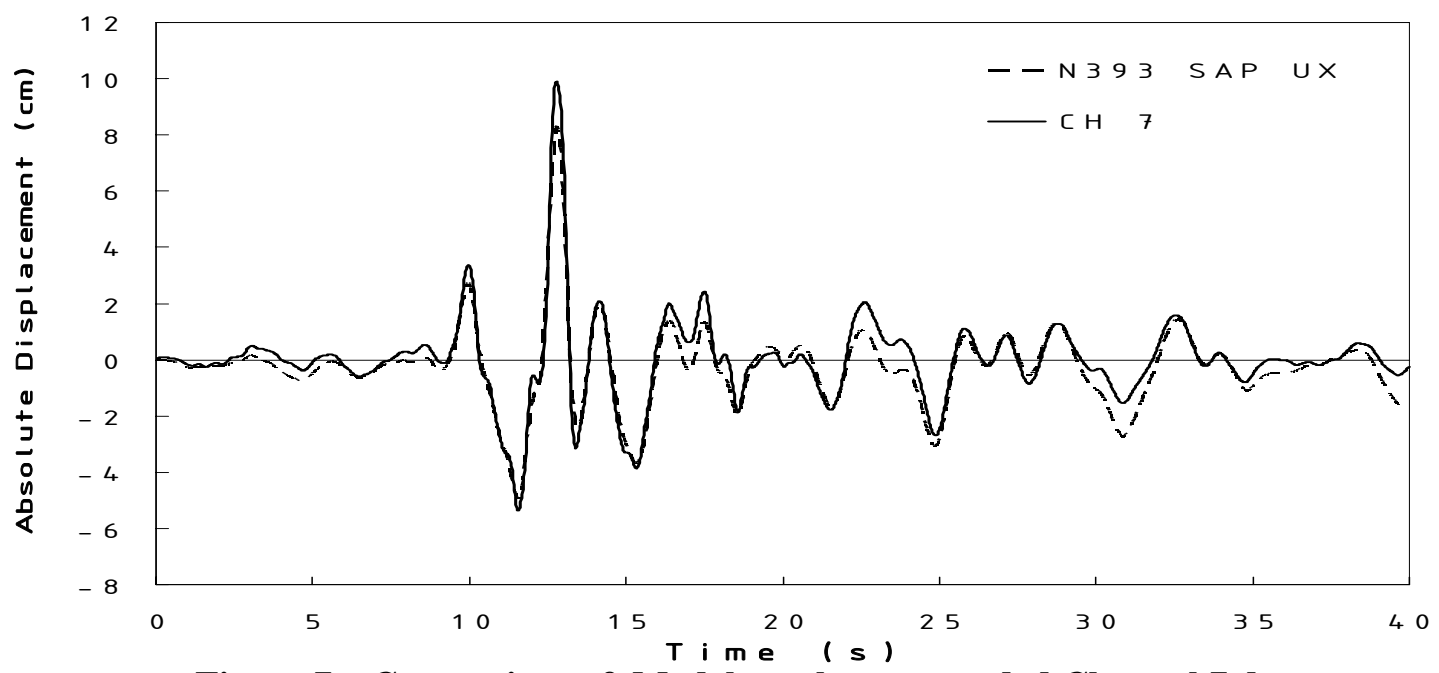

Figure 7 - Comparison of Model results to recorded Channel 7 data

Loma Prieta and Level II pile forces. Design axial, shear and moment capacity and the flexural cracking moment were calculated for the support piles. Calculations were made as described in the Building Code requirements for Structural Concrete (ACI 318-02) and Commentary (ACI 318R-02) (ACI, 2002). A summary of the percentage of piles with seismically induced demand exceeding capacity is given in Table 2. Under the Loma Prieta ground motions, none of the modeled piles developed forces exceeding design strength or 
cracking capacities. Time history analyses using the Kobe ground motions showed that 51\% of the vertical piles and $15 \%$ of the batter piles exceeded flexural cracking loads, but none

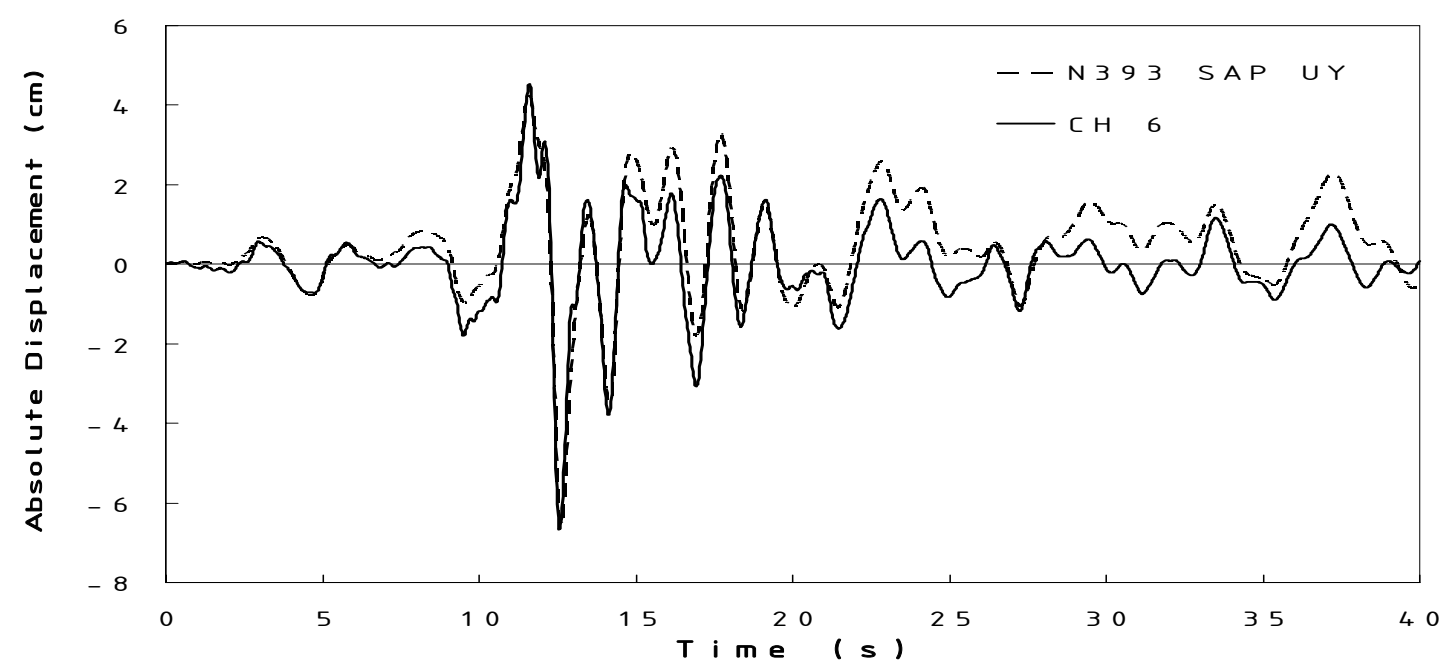

Figure 8 - Comparison of Model results to recorded Channel 6 data

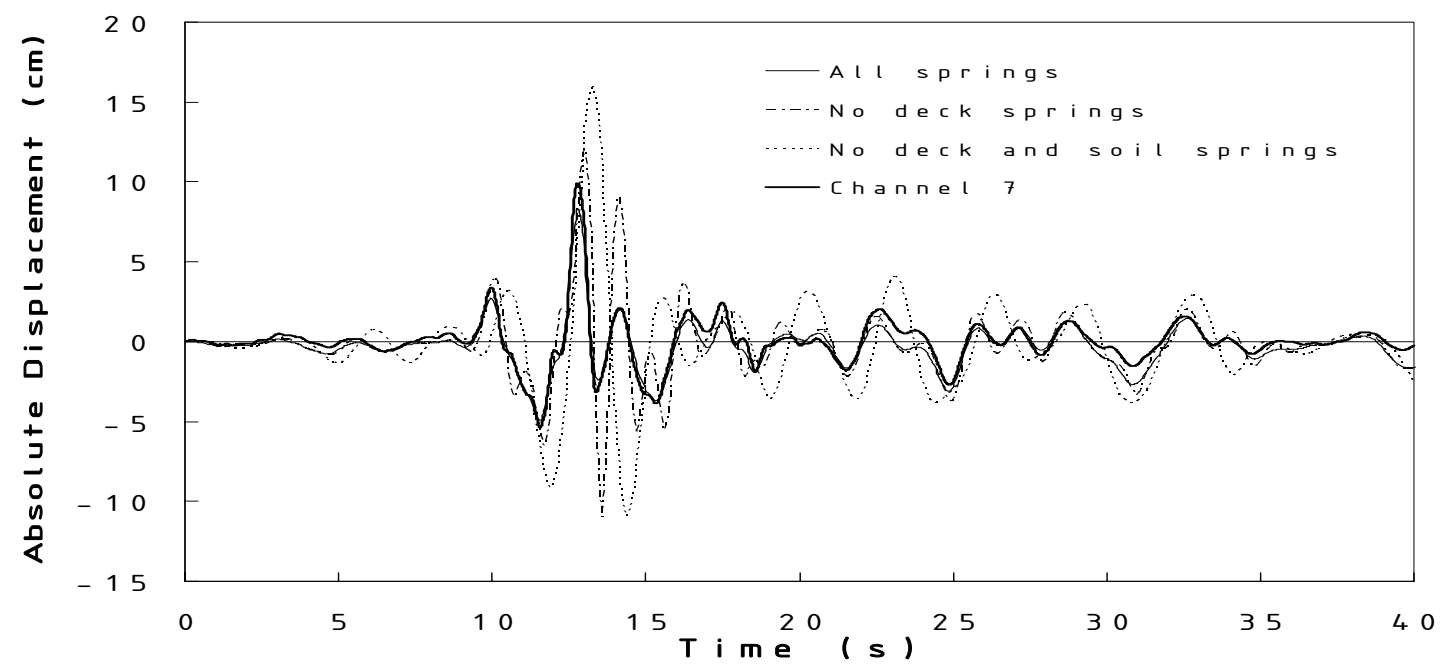

Figure 9 - Comparison of Model results with and without soil and deck springs

exceeded any type of design strength. Most modeled piles exceeding flexural cracking loads are located in pile rows $\mathrm{B}$ and $\mathrm{E}$ (vertical) and pile row $\mathrm{C}$ (outboard batter). Exceeding flexural cracking loads in these piles were typically located at the upper most node attached to a spring element. This location is approximately equal to an average depth below the design mudline of five pile diameters. Responses developed as a result of time history analyses are further illustrated by calculating the average ratio of seismically induced demand to capacity as shown in Table 3. As expected, average ratios for each pile row are larger for Kobe versus Loma Prieta ground motions. However, this difference is not as pronounced for axial demand on vertical piles (rows A through E) due to the lack of a vertical component in the modeled ground motions. A vertical component was not included in either of the input ground motions to facilitate comparison of modeled data. Vertical motion data were not available for the SMD recorded at Berth 24/25 at the location of channels 1 and 3. 


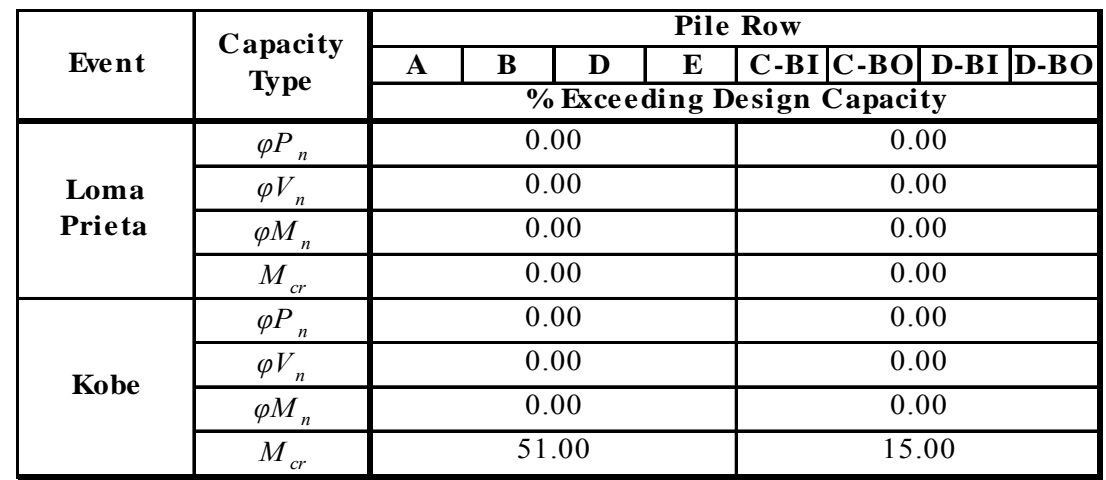

BI - Batter Inboard

BO - Batter Outboard

Table 2 - Summary of piles with seismic demand exceeding design capacity

\begin{tabular}{|c|c|c|c|c|c|c|c|c|c|}
\hline \multirow{3}{*}{ Event } & $\begin{array}{c}\text { Demand to } \\
\text { Capacity } \\
\text { Ratio }\end{array}$ & \multicolumn{9}{|c|}{ Pile Row } \\
\cline { 2 - 10 } & A & B & C & E & C-BI & C-BO & D-BI & D-BO \\
\hline \multirow{3}{*}{$\begin{array}{c}\text { Loma } \\
\text { Prieta }\end{array}$} & $P / \varphi P_{n}$ & 0.20 & 0.22 & 0.25 & 0.05 & 0.31 & 0.23 & 0.28 & 0.20 \\
\cline { 2 - 11 } & $V / \varphi V_{n}$ & 0.04 & 0.07 & 0.06 & 0.11 & 0.07 & 0.10 & 0.08 & 0.10 \\
\cline { 2 - 11 } & $M / \varphi M_{n}$ & 0.05 & 0.06 & 0.15 & 0.26 & 0.08 & 0.13 & 0.18 & 0.13 \\
\cline { 2 - 11 } & $M / M_{c r}$ & 0.11 & 0.14 & 0.34 & 0.59 & 0.19 & 0.30 & 0.41 & 0.29 \\
\hline \multirow{3}{*}{ Kobe } & $P / \varphi P_{n}$ & 0.20 & 0.23 & 0.27 & 0.05 & 0.51 & 0.38 & 0.45 & 0.36 \\
\cline { 2 - 10 } & $V / \varphi V_{n}$ & 0.28 & 0.41 & 0.26 & 0.39 & 0.22 & 0.34 & 0.26 & 0.30 \\
\cline { 2 - 10 } & $M / \varphi M_{n}$ & 0.35 & 0.47 & 0.40 & 0.65 & 0.31 & 0.44 & 0.42 & 0.41 \\
\cline { 2 - 10 } & $M / M_{c r}$ & 0.82 & 1.09 & 0.92 & 1.50 & 0.72 & 1.01 & 0.96 & 0.96 \\
\hline
\end{tabular}

Table 3 - Average ratio of seismic demand to capacity

This analysis did not include subsurface loading to the support piles caused by seismically-induced soil deformation. Recent work has shown that post-earthquake residual loading (i.e. due to liquefaction or other types of permanent slope deformation) may cause demands that exceed pile capacity whereas the demand from transient, inertial loads do not (McCullough et al., 2001). It is also interesting to note that although little damage is observable for Berth 24/25 from recorded or modeled data, other Port facilities did suffer substantial damage during the Loma Prieta earthquake. This is evident from the severe damage that occurred at the $7^{\text {th }}$-Street terminal which is constructed similarly to Berth 24/25 (i.e. vertical and batter support piles) and is proximate to it. Damage at the $7^{\text {th }}$-Street terminal included shear failure of support piles at the pile-cap interface and permanent deformation of the soil slope below the wharf (Egan et al., 1992).

\section{CONCLUSIONS}

Empirical analysis of SMD gathered from Berth 24/25 at the Port of Oakland has been used to illustrate dynamic structural response. Scrutiny of absolute displacement-time histories indicates that a low amount of wharf torsion was caused by ground motions generated during the Loma Prieta earthquake It is therefore unlikely that below grade components of the wharf were damaged due to torsional motion during the Loma Prieta event. This conclusion is supported by post-event inspections that showed little or no damage to exposed wharf support piles (Serventi, 2003). Other modes of seismic damage to waterfront facilities are commonly due to soil liquefaction and permanent ground 
deformation. Analysis of absolute and relative displacement-time histories illustrate that increased pore pressure generation and possibly full liquefaction at intermittent locations is likely to have occurred in the Northeast portion of backland soils. Lower bound SPT Nvalues in this area ranged from 6 to 22 blows $/ 30 \mathrm{~cm}$ (Port of Oakland, 1977). A lengthening of period observable for the channel 10 absolute displacement plot indicates moderate liquefaction of soils in this area and is supported by clear evidence of ground settlement observed in the Northeast wharf backland after the Loma Prieta earthquake (Serventi, 2003). The nature and extent of information gathered concerning wharf performance for Berth 24/25 at the Port of Oakland based on empirical analysis of SMD makes a strong case for the increased deployment of instrumentation at waterfront facilities in seismically active regions of the United States.

Accuracy of 3D model output time histories for Berth 24/25 was found to be strongly dependent on proper inclusion of springs representing pile-soil and wharf-sheet pile wall interaction. For the low level of shaking that occurred at Berth 24/25 during the Loma Prieta event and for ground motions associated with the Level II design event (Kobe), the nonlinear soil springs never exceeded the elastic stiffness range. However, $\mathrm{K}_{\mathrm{sec}}$ values for the elastic portion of the non-linear springs yielded well matched modeling results. The structural model used for this project did not capture post yield behavior of frame elements. Therefore, estimates of response are made using the initial uncracked stiffness. Application of design level ground motions to this model showed pile moments exceeding the Level II limit state as defined by the Port. Thus, the analysis under Level II ground motions was only useful in gathering a rough estimate of the amount of damage to be expected during a similar event.

It should also be noted that 3D structural models do not incorporate pile loads caused by slope deformations, which have been shown to cause subsurface failure in piles (McCullough et al., 2001; McCullough, 2003; Roth and Dawson, 2003; Roth et al., 2003). A primary benefit of comparison of 3D model output to recorded data then, is in establishing the initial elastic soil and sheet pile-spring values for use in subsequent pushover analyses. Future work should include examination of model behavior once soils springs have been pushed to the non-linear range, and 2D non-linear pushover analyses for comparison to those previously conducted as part of the WESP.

\section{ACKNOWLEDGMENTS}

The authors wish to thank the following for their support in this project:

- Mr. Tom Labasco, Principal Engineer, and Mr. Gerald Serventi, Director of Engineering, Port of Oakland

- Technical Support, Computer and Structures, Inc.

- Dr. Nason McCullough, Project Engineer, CH2M HILL

- Dr. Moh J. Huang, Deputy Program Manager, State of California Department of Conservation, Office of Strong Motion Studies 


\section{REFERENCES}

ACI Committee 318 (2002), "Building Code Requirements for Structural Concrete (318-02) and Commentary (318R-02)," American Concrete Institute, Farmington Hills, Michigan.

American Petroleum Institute (1987), "Recommended Practice for Planning, Designing and Constructing Offshore Platforms", API Recommended Practice $2 A$ (RP 2A), Seventeenth Addition, Washington, D.C.

California Department of Conservation Division of Mines and Geology (1989), "California Strong Motion Implementation Program Strong-Motion Records from the Santa Cruz Mountains (Loma Prieta), California Earthquake of 17 October 1989," California Department of Conservation Division of Mines and Geology Office of Strong-Motion Studies Report OSMS 89-06C, Sacramento, California.

CH2M HILL and Ben C. Gerwick (2000), "Wharf and Embankment Seismic Risk Evaluation Report," Port of Oakland Wharf Embankment and Strengthening Program (WESP) Berths 23, 24 and 25, Oakland, California.

Computers and Structures, Inc. (2000), "SAP2000: Static and Dynamic Analysis of Finite Element Structures Nonlinear v7.50," Berkeley, California.

EduPro Civil Systems, Inc. (1999), "ProShake version 1.10," Redmond, Washington.

Egan, J.A., Hayden, R.F., Scheibel, A., Mahmut, O., Serventi, G. (1992), "Seismic Repair at Seventh Street Marine Terminal," Proceedings of the Conference on Grouting, Soil Improvement and Geosynthetics, Volume 2, Geotechnical Special Publication No. 30, American Society of Civil Engineers, New York, New York, pp. 867-878.

International Navigation Association (PIANC) (2001), "Seismic Design Guidelines for Ports Structures: Working Group No. 34 of the Maritime Navigation Commission," A.A. Balkema Publishers, Exton, Pennsylvania, p. 23.

Johnson, R.K., Riffenburgh, R., Hodali, R., Moriwaki, Y., Tan, P. (2001), "Analysis and Design of a Container Terminal Wharf at the Port of Long Beach," Proceedings of the Ports '01 Conference, American Society of Civil Engineers, Reston, Virginia, pp. 436444.

Labasco, T. (2002), "Presentation: Port of Oakland Earthquake Engineering Issues," Oregon State University Port and Harbor Engineering Seminar, Oregon State University, Corvallis, Oregon.

Lobedan, F., Labasco, T., Ogunfunmi, K. (2001), "Wharf Embankment and Strengthening Program at the Port of Oakland," Proceedings of the Ports '01 Conference, American Society of Civil Engineers, Reston, Virginia.

McCullough, N.J. (2003), "The Seismic Geotechnical Modeling, Performance and Analysis of Pile-Supported Wharves," PhD Dissertation, Oregon State University, Corvallis, Oregon.

McCullough, N.J., Dickenson, S.E., and Schlechter, S.M. (2001), "The Seismic Performance of Piles in Waterfront Applications," Proceedings of the Ports '01 Conference, American Society of Civil Engineers, Reston, Virginia. 
Norris, G., Siddharthan, R., Zafir, Z. Abdel-Ghaffar, S., Gowda, P. (1991), "Soil-FoundationStructure Behavior at the Oakland Outer Harbor Wharf," Proceedings of the SMIP91 Seminar on Seismological and Engineering Implications of Recent Strong-Motion Data, California Department of Conservation Division of Mines and Geology, Sacramento, California, Section 11, pp. 1-11.

Pacific Earthquake Engineering Research Center (PEER) (2003), "PEER Ground Motions," PEER Ground Motion Workshop, http://peer.berkely.edu/research/motions.

Port of Oakland (2003), "Port of Oakland Maritime Terminal Specifications," http://www.portofoakland.com/maritime/terminal.asp.

Port of Oakland (1977), “Outer Harbor Terminal As-built Plans," Construction of Concrete Berths 2, 3 and 4, Oakland, California.

Roth, W.H. and Dawson, E.M. (2003), "Analyzing the Seismic Performance of Wharves, Part 2: SSI Analysis with Non-linear, Effective Stress Models," TCLEE 2003: Sixth US Conference and Workshop on Lifeline Earthquake Engineering, American Society of Civil Engineers, Reston, Virginia.

Roth, W.H., Dawson, E.M., Mehrain, M., Sayegh, A. (2003), "Analyzing the Seismic Performance of Wharves, Part 1: Structural Engineering Approach," TCLEE 2003: Sixth US Conference and Workshop on Lifeline Earthquake Engineering, American Society of Civil Engineers, Reston, Virginia.

Seed, H.B. and Idriss I.M. (1970), "Soil Moduli and Damping Factors for Dynamic Response Analyses," Report No. EERC 70-10, Earthquake Engineering Research Center, University of California, Berkeley.

Seed, H.B., Wong, R.T., Idriss, I.M., and Tokimatsu, K. (1986), "Moduli and Damping Factors for Dynamic Analyses of Cohesionless Soils," Journal of Geotechnical Engineering, ASCE, Vol. 112, No. 11, pp. 1016-1032.

Serventi, G.M. (2003), Personal communication.

Technical Council on Lifeline Earthquake Engineering (TCLEE) (1998), "Seismic Guidelines for Ports, Edited by Stuart D. Werner," TCLEE Ports Committee Monograph No. 12, American Society of Civil Engineers, Reston, Virginia.

URS Greiner Woodward Clyde (2000), "Phase-I Geotechnical Report on Ground Motions Volume I," Port of Oakland Wharf Embankment and Strengthening Program (WESP) Berths 60-63 and 23-25, Oakland, California.

US Department of Transportation (1996), "Publication No. FHWA-HI-97-013 - Design and Construction of Driven Pile Foundations," NHI Course Nos. 13221 and 13222 Workshop Manuals Volumes 1 and 2, Washington, D.C.

Vucetic, M. and Dobry, R. (1991), "Effect of Soil Plasticity on Cyclic Response," Journal of Geotechnical Engineering, ASCE, Vol. 117, No. 1, pp. 89-107.

United States Department of the Interior U.S. Geological Survey (1992), "Seismic Velocities and Geologic Logs from Borehole Measurement at Seven Strong-Motion Stations that 
Recorded the 1989 Loma Prieta Earthquake," U.S. Geological Survey Open-File Report 92-287, Menlo Park, California.

Weismair, M., Sharestani, S., Angel, L., Priestley, N., Koo, W., (1998), "Seismic Design of Port of Los Angeles Berth 144 Wharf," Proceedings of the Ports '98 Conference, American Society of Civil Engineers, Reston, Virginia, pp. 426-435.

Weismair, M., Sharestani, S., Angel, L., Priestley, N., Lam, I.P., (2001), "Seismic Design of Port Los Angeles Pier 400 Container Wharf," Proceedings of the Ports '01 Conference, American Society of Civil Engineers, Reston, Virginia. 